\title{
Peningkatan Mutu Sekolah melalui Manajemen Hubungan Masyarakat
}

\author{
Rachmat Satria*, Achmad Supriyanto, Agus Timan, Maulana Amirul Adha \\ Universitas Negeri Malang, Malang, Indonesia \\ *Corresponding Author. Email: satriarachmat7@gmail.com
}

\begin{abstract}
Abstrak
Tujuan penelitian ini yakni untuk mendeskripsikan, (1) manajemen hubungan masyarakat dengan sekolah, (2) prosedur operasional hubungan masyarakat di sekolah, dan (3) peran kepala sekolah dalam meningkatkan mutu sekolah. Metode penelitian menggunakan pendekatan kualititatif dengan rancangan penelitian studi kasus. Lokasi penelitian di SMPN 15 Malang. Teknik pengumpulan data diperoleh melalui observasi, wawancara mendalam dan studi dokumentasi. Hasil penelitian ini yakni (1) manajemen hubungan masyarakat dalam peningkatan mutu sekolah secara internal maupun eksternal meliputi dimensi perencanaan, pelaksanaan dan evaluasi pihak sekolah dalam merancang program-program sekolah, (2) prosedur operasional hubungan masyarakat di sekolah meliputi pertemuan kepala sekolah dengan komite dan masyarakat dalam mensosialisasikan citra sekolah serta pengadaan infrastruktur sarana dan prasarana pendidikan, pertemuan unsur sekolah dengan orang tua peserta didik untuk pengambilan buku raport siswa, mengatur strategi hubungan kerjasama unsur sekolah seperti; perkemahan, gotong royong, visit school, serta kegiatan perlombaan, dan mengatur koordinasi hubungan kerjasama antar lembaga pendidikan terhadap feedback penyelenggaraan program kerja sekolah, dan (3) peran pemimpin sekolah yakni dengan mengaplikasikan konsep manajemen pendidikan, serta monitoring pada setiap aspek komponen manajemen pendidikan di sekolah.
\end{abstract}

Kata Kunci: Kepemimpinan Kepala Sekolah, Manajemen Hubungan Masyarakat, Mutu Sekolah

\section{School Quality Improvement through Public Relationship Management}

\begin{abstract}
The purpose of this study is to describe, (1) management of public relations with schools, (2) operational procedures for public relations in schools, and (3) the role of principals in improving school quality. The research method uses a qualitative approach with a case study research design. The research location is in SMPN 15 Malang. Data collection techniques were obtained through observation, in-depth interviews and documentation studies. The results of this study are (1) management of public relations in improving the quality of schools internally and externally covering the dimensions of planning, implementation and evaluation of the school in designing school programs, (2) operational procedures for community relations in schools including meeting principals with committees and the community in disseminating the image of the school as well as the procurement of educational facilities and infrastructure infrastructure, meeting elements of the school with parents of students to retrieve student report, set up strategy of cooperative relations between school elements such as; camp, mutual cooperation, visit school, and event activities, and regulate the coordination of collaborative relationships between educational institutions with regard to feedback on the implementation of school programs, and (3) the role of principal by applying educational management concepts and monitoring on every aspect of education management components in school.
\end{abstract}

Keywords: Principal Leadership, Public Relationship Management, School Quality 


\section{PENDAHULUAN}

Sekolah merupakan lembaga pendidikan sebagai wadah dalam mentransformasikan keseimbangan antara nilai dan moral kepada peserta didik dalam proses penyelenggaraan pembelajaran, sekolah dituntut untuk berupaya melakukan inovasi-inovasi untuk meningkatkan mutu pendidikan dalam memajukan kualitas kelembagaan secara nasional. Program-program pendidikan yang dijalankan harus mengedepankan pada setiap aspek komponen elemen pelaksanaan pendidikan untuk meliputi pengembangan dan pembentukan karakter peserta didik. Dalam konteks pendidikan di sekolah, Sekolah menengah Pertama (SMP) memiliki peranan penting yang merupakan bagian dari pendidikan dasar bagi peserta didik dalam menunjang sistem pendidikan nasional. Sekolah sebagai pusat penyelenggara pendidikan berperan dalam meningkatkan mutu pendidikan masa depan agar mampu mencetak output sumber daya berkualitas (Adha, Benyamin, Octaviarnis, \& Thalib, 2019).

Pendidikan adalah investasi pembangunan bangsa dapat ditinjau dari kualitas sumber daya manusia yang dimiliki, aspek ini ditinjau dari input, proses dan output serta outcomes dari sekolah tersebut. Peran sekolah untuk memaksimalkan kualitas dari sumber daya manusia itu didukung dengan pola manajemen yang terstruktur dalam proses pembelajaran peserta didik dalam peningkatan mutu pendidikan. Wahjosumidjo (2010) menyatakan bahwa penerapan program-program mutu pendidikan dilakukan untuk menyempurnakan komponen pembelajaran di sekolah. Pendidikan membangun mutu peserta didik dalam menghadapi gejolak perkembangan zaman. Mutu tersebut dinilai dari tingkat kepuasan masyarakat sebagai konsumen dari layanan lembaga pendidikan tersebut.

Proses peningkatan mutu pendidikan tersebut tentunya melalui langkah strategis manajemen sekolah dalam upaya meningkatkan kualitas sekolah. Strategi manajemen merupakan langkah upaya memenuhi kebutuhan pendidikan dalam meningkatkan kualitas mutu peserta didik (Ayu \& Septi, 2012). Mutu sebagai bentuk layanan untuk memenuhi kebutuhan dan harapan peserta didik dimana mutu tersebut secara langsung berorientasi pada ilmu pengetahuan dan teknologi. Artinya, manajemen mutu terpadu dalam bidang pendidikan bersifat continues improvement yang secara berkesinambungan untuk memperbaiki dan memenuhi kebutuhan yang diharapkan bagi peserta didik dalam suatu layanan penyelenggaraan pendidikan. Namun, Sutrisno \& Rusdi (2007) menjelaskan bahwa upaya perbaikan mutu pendidikan meliputi komponen kurikulum, infrastruktur pembelajaran, tenaga pengajar dan kependidikan di Indonesia masih dikategorikan rendah dan belum terlihat hasil yang signifikan.

Persaingan global dunia pendidikan yang semakin pesat menuntut sekolah untuk terus berbenah dalam program pendidikan agar dapat mempertahankan eksistensinya di dunia pendidikan, sistem manajemen yang terencana tentunya dibutuhkan dalam upaya pemaksimalan kompetensi sekolah agar terciptanya program-program pendidikan yang bermutu. Sekolah dikatakan bermutu bila berkorelasi dengan perkembangan kualitas peserta didik. Kualitas pendidikan dikonstruksikan agar memberikan daya saing bagi peserta didik baik di sekolahnya maupun diluar wilayah sekolahnya (Asmi \& Sahuri, 2013). Maka dari itu peranan kepala sekolah dalam mengelola manajemen sekolah dengan daya pikir yang kreatif, inovatif dan rensponsif untuk meningkatkan mutu pendidikan. Pendidikan yang bermutu terselenggara dalam bentuk impelementasi manajemen strategik yang tepat, Muniarti (2008) mengemukakan bahwa manajemen strategik sebagai siklus untuk melahirkan keputusan yang relevansi dengan kebutuhan dari lembaga pendidikan tersebut sehingga dapat menyesuaikan dengan perubahan untuk meningkatkan produktivitas dan efektivitas dari pada program pembelajaran.

Kegiatan proses pembelajaran dalam pendidikan tidak mungkin dan tidak dapat dilepaskan dari latar belakang yang melingkupinya, terdapat berbagai hal dalam landasan- 
landasan pendidikan yang harus dipahami sebagai seorang tenaga pendidik yang profesional. Salah satu langkah strategis yang dapat diimplementasikan dalam peningkatan mutu pendidikan sekolah melalui peranan manajemen hubungan masyarakat (Humas), peranan ini sangat mendukung terhadap keberhasilan program pembelajaran terutama dalam mengeksternalisasi visi dan misi sekolah tersebut (Kowalski, 2011 p.13). Manajemen humas yang bagus dan terarah akan membantu sekolah untuk mendapatkan kepercayaan dari masyarakat untuk mendukung peningkatan mutu sekolah, keterlibatan masyarakat serta komunikasi yang baik sangat penting bagi keberlangsungan kemajuan sekolah. Sebagaimana yang diamanatkan dalam Undang-Undang Republik Indonesia No. 20 Tahun 2003 Pasal 7 ayat (1) dijelaskan bahwa wali murid bepartisipasi dalam menentukan satuan pendidikan dan mendapatkan informasi kemajuan pendidikan anaknya. Seluruh kegiatan program sekolah memerlukan partisipasi orang tua dan masyarakat untuk menunjang kesuksesan peningkatan mutu pendidikan (Ariyanti, Sobri, \& Kusumaningrum, 2018).

Dalam masyarakat modern, hubungan masyarakat dan sekolah menjadi semakin kompleks. Sebagai sistem terbuka, sekolah berada dalam hubungan timbal balik dengan masyarakat serta sejumlah besar organisasi. Untuk alasan ini, hubungan masyarakat telah menjadi tren umum untuk memperkuat hubungan, koordinasi dan komunikasi antara sekolah dan organisasi sosial lainnya. Citra sekolah juga didirikan dan dikembangkan dalam proses ini (Tianping, 2003; Adil, 2018). Hubungan masyarakat adalah proses yang membantu menjaga dan memelihara komunikasi timbal balik, pemahaman, penerimaan, dan kerja sama antara lembaga dan kelompok sasarannya (Peltekoğlu dalam Adil, 2018). Manajemen hubungan sekolah dan masyarakat penting dapat dimaksimalkan dalam upaya peningkatan mutu pendidikan disekolah. Berdasarkan jabaran diatas maka tujuan dari penelitian ini yakni untuk mendeskripsikan, (1) manajemen hubungan masyarakat dengan sekolah, (2) prosedur operasional hubungan masyarakat di sekolah, dan (3) peran kepala sekolah dalam meningkatkan mutu sekolah.

\section{METODE PENELITIAN}

Penelitian ini dilakukan di SMP Negeri 15 Malang untuk menggali informasi secara mendalam mengenai mutu pendidikan, studi penelitian menggunakan metode penelitian kualitatif untuk mengetahui dan mengungkap fakta serta memperoleh informasi secara natural di lapangan dengan rancangan penelitian studi kasus (Ulfatin, 2015). Metode kualititatif merupakan metode-metode untuk mengeksplorasi dan memahami makna yang oleh sejumlah individu atau sekelompok orang berasal dari masalah sosial atau kemanusiaan (Creswell, 2014).

Data yang diperoleh berkaitan dengan manajemen humas, prosedur operasional humas serta peran kepala sekolah dalam peningkatan mutu sekolah. Teknik pengumpulan data diperoleh melalui observasi berpartisipasi, wawancara mendalam dan studi dokumentasi. Sumber data penelitian berupa dokumen-dokumen program kerja sekolah serta melalui wawancara terbuka dengan Wakil Bidang Humas, guru senior serta Kepala Sekolah sebagai informan.

Peneliti melakukan analisis data dengan cara mereduksi data yang telah diperoleh sebelumnya, data kemudian disajikan dan dilakukan sebuah penarikan kesimpulan. Penelitian ini dilakukan pengecekan keabsahan data untuk mempertanggungjawabkan kebenaran data dengan teknik kredibelitas, kecukupan bahan referensi, ketergantungan dan kepastian. 


\section{HASIL DAN PEMBAHASAN}

\section{Manajemen Hubungan Masyarakat dengan Sekolah}

Hubungan masyarakat dengan pihak sekolah harus dikelola secara baik dan efektif, melibatkan peran masyarakat secara optimal mendukung peningkatan kualitas mutu pendidikan. Hubungan antara lingkungan sekolah dan masyarakat bernilai positif dengan harapan tercapainya produktivitas pendidikan secara efektif dan efisien dalam menghasilkan kualitas mutu pendidikan. Pendidikan merupakan kewajiban bersama antara sekolah, wali murid dan masyarakat yang secara beriringan membangun pendidikan. Dalam mengelola hubungan masyarakat dengan sekolah tentunya dibutuhkan proses perencanaan, pelaksanaan dan evaluasi pihak sekolah dalam merancang program-program secara internal maupun eksternal dalam aktivitas sekolah. Perencanaan terstruktur tentunya meliputi tujuan dan sasaran yang jelas terutama berhubungan dengan aspek peningkatan mutu sekolah tersebut.

Berdasarkan temuan di sekolah, adapun program perencanaan yang dilakukan oleh SMPN 15 Malang diantaranya: (1) perencanaan yang dilakukan oleh Kepala Urusan Humas diantaranya: (1) program perencanaan hubungan masyarakat melibatkan seluruh elemen lingkungan sekolah; (2) proses perencanaan hubungan masyarakat memiliki fungsi, tujuan dan sasaran yang dibahas melalui agenda rapat pelaksanaan kegiatan sekolah; (3) program hubungan masyarakat diaplikasikan melalui kerjasama antara sekolah dengan stakeholder pendidikan, orang tua maupun masyarakat meliputi kegiatan eksternal dan internal sekolah. Keseluruhan bentuk program perencanaan tersebut dibentuk dalam rangka peningkatan mutu sekolah dalam menyikapi daya saing dengan sekolah unggulan lainnya, perencanaan yang baik dan terinci dapat mempermudah pihak sekolah dalam mencapai tujuan yang diharapkan ke depan.

Perumusan perencanaan program Humas tersebut juga berorientasi dengan visi dan misi sekolah yang terdiri dari standar pengelolaan sistem pendidikan nasional (SNP). Lebih lanjut bahwa untuk mencapai program-program yang lebih optimal ke depan maka penyusunan juga harus mempertimbangkan terhadap aspek-aspek lainnya seperti kondisi geografis sekolah, sosial-kultural, dan anggaran pendanaan yang dimiliki oleh sekolah, hal tersebut mejadi dasar langkah strategis yang optimal dalam mencapai hasil yang efektif, efisien dan berhasil bagi penyelenggaraan pendidikan. School Based Management menjadi program peningkatan mutu sekolah dimana program layanan ini berupaya melakukan kerjasama dengan stakeholder pendidikan dalam peningkatan kemandirian sekolah, kemitraan dan partisipasi terbuka untuk mewadahi hubungan sekolah dengan masyarakat. Hal ini sejalan dengan pendapat Dhuhani (2016) mengemukakan bahwa manajemen humas berproses secara integral dengan manajemen berbasis sekolah dibawah tuntunan kepala sekolah dan komite sekolah.

Perencanaan menggambarkan bagian pokok dari fungsi manajemen hubungan masayarakat di sekolah. Perencanaan juga memiliki sasaran dan tujuan untuk mengukur indikator pencapaian yang akan dicapai. Dalam hal ini sekolah merumuskan konsep manajemen humas dengan sekolah berupaya menarik antusiasme masyarakat melalui bentuk program pendidikan yang diharapkan bersama. Adapun menurut Suryosubroto (2012) fungsi interaksi sekolah dengan masyarakat diantaranya, (1) koordinasi terhadap interaksi sekolah dengan orang tua; (2) menjaga relasi hubungan baik dengan komite sekolah; (3) merawat dan mengembangkan hubungan sekolah dengan lembaga dan instansi pemerintah serta organisasi nasional; dan (4) menyampaikan arahan bagi masyarakat perihal manajemen sekolah melalui beragam teknik komunikasi. Fungsi tersebut bertujuan meningkatkan popularitas sekolah di mata masyarakat dengan menciptakan program mutu pendidikan yang relevan dengan kebutuhan individu peserta didik yang mapan secara intelektual dan spiritual dalam kehidupan bermasyarakat. 
Sementara itu, sasaran hubungan sekolah dengan masyarakat diantaranya: (1) sebagai perantara komunikasi dari internal sekolah dengan masyarakat selakukolega sekolah mencapai kejayaan sekolah dalam menciptakan peserta didik yang cerdas, berkarakter mampu mengamalkan ilmu yang diperolehnya dalam menggerakkan masyarakat; (2) menciptakan interaksi yang harmonis dengan elemen masyarakat agar mendapatkan dukungan terhadap penyelenggaran pendidikan; dan (3) mencari aspirasi dan simpati dari masyarakat.

Seluruh rangkaian diatas bertujuan untuk menjaga hubungan baik sekolah dengan seluruh lapisan elemen masyarakat agar turut berpatisipasi aktif dengan dunia pendidikan. Suryosubroto (2012) mengemukakan bahwa perencanaan dalam program Humas sebagai langkah persiapan program pendidikan yang akan dicapai dan diinformasikan kepada masyarakat. Senada dengan pendapat Brown dan Mark (dalam Ruslan, 2007) menjelaskan bahwa manajemen Humas sebagai suatu perencanaan pelaksanaan dan evaluasi terhadap kegiatan-kegiatan dalam menyebarkan informasi kepada publik melalui berbagai mediamedia komunikasi. Hubungan masyarakat dibangun melalui kerjasama sehingga pelaksanaan program pendidikan terselenggara dengan kolaborasi yang positif untuk memaksimalkan sasaran yang ingin dicapai.

Program-program perencanaan yang telah disusun tersebut kemudian diimplementasikan. Proses pelaksanaan program Humas dengan melibatkan berbagai elemen sekolah melalui binaan dari kepala sekolah dan jajaran lainnya. Program-program perencanaan bidang hubungan masyarakat untuk membantu mengefektifkan peran kepala sekolah dimana pelaksanaan dilakukan secara operasional setiap harinya. Namun, dalam struktur organisasi dan personalia sekolah, dimana wakil kepala bidang kesiswaan dengan bidang kehumasan digabungkan menjadi satu bagian guna lebih mengefektifkan programprogram kegiatan yang berlangsung di sekolah tersebut pada tahun ajaran saat ini, programprogram kehumasan tidak mendapatkan bagiannya dikarenakan pada urusan data Dapodik yang diakui di dalam kelembagaan hanya bidang kurikulum, bidang kesiswaan dan bidang sarana prasarana. Akan tetapi, dalam hal ini kepala sekolah tetap memasukkan bidang kehumasan dalam struktural kelembagaan, maka dari itu digabungkannya struktur kelembagaan kesiswaan dan kehumasan menjadi satu bagian dalam kegiatan pembelajaran dan tetap dipisahkan menurut tujuannya masing-masing walaupun diwadahi dalam satu bidang, setiap masing-masing bidang kesiswaan dan kehumasan dibantu oleh seksi bidang tersendiri.

Berdasarkan temuan di sekolah, pelaksanaan kegiatan dalam program Humas diantaranya meliputi; Pertama, Kegiatan eksternal yaitu kegiatan yang difokuskan kepada lembaga/institusi dan masyarakat di luar sekolah.Terdapat dua kegiatan utama diantaranya: (1) Indirect act berupa kegiatan sekolah yang dihubungkan dengan masyarakat melalui wadah media informasi seperti website Sekolah, demonstrasi karya dan majalah sekolah; (2) Direct act berupa kegiatan sekolah yang difokuskan pada masyarakat secara langsung seperti rapat komite sekolah, tukar pikiran dengan pilar-pilar masyarakat, dan kunjungan tamu. Dan Kedua, Kegiatan internal yaitu penyebaran beritakepada warga sekolah. Terdapat dua kegiatan utama diantaranya: (1) Indirect act berupa aktivitas internal melalui sarana informasi sekolah seperti pamflet sekolah, buletin/majalah sekolah, iklan media massa, dan drama sekolah; (2) Direct act berupa aktivitas internal program pengembangan warga sekolah seperti rapat dewan guru, studi banding, dan rekreasi. Dengan makna lain bahwa program Humas bagian luar (eksternal) memberitahukan mengenai identitas sekolah, sedangkan untuk kehumasan bagian dalam (internal) yaitu memfasilitasi guru, karyawan, dan peserta didik tentang apa yang dibutuhkan dan program-program yang akan diselenggarakan oleh sekolah.

Pelaksanaan program Humas memiliki efek yang besar dan strategis dalam membina serta penceiptaan iklim yang kondusif dalam hubungan antara masyarakat dan sekolah (Grace \& Harrington, 2015), maka tugas pokok Kepala urusan Humas diharapkan dapat membantu 
kepala sekolah dalam menyiapkan kegiatan-kegiatan pendukung peningkatan mutu pendidikan. Terdapat beberapa tugas pokok Kepala urusan Humas diantaranya: (1) membuka akses informasi dan penyampaian gagasan kepada masyarakat; (2) mengakomodasi kepala sekolah mengembangkan rencana dan kegiatan lanjutan pendidikan; (3) menyampaikan informasi yang berkembang di tengah masyarakat tentang masalah pendidikan; (4) berkontribusi terhadap peran kepala sekolah untuk memperoleh bantuan dan kerjasama; dan (5) menyusun laporan pelaksanaan kegiatan Humas secara berkala. Suryosubroto (2012) menyatakan bahwa pelaksanaan program kegiatan dapat terlaksana sebagaimana yang telah dipersiapkan dan direncanakan. Komunikasi serta kerjasama sangat penting dalam membangun citra positif sekolah menjadi lebih baik (Tianping, 2003; Adil, 2018). Penciptaan citra sekolah yang baik membutuhkan pengelolaan secara optimal hubungan masyarakat dan sekolah yang nantinya menciptakan interaksi positif antara sekolah dan masyarakat.

Tahapan selanjutnya adalah evaluasi, kegiatan ini untuk meninjau terhadap kendala dalam pelaksanaan manajemen hubungan sekolah dan masyarakat di sekolah, evaluasi akan menjadi tolak ukur terhadap keberhasilan pelayanan pendidikan dalam peningkatan kualitas mutu sekolah. Berdasarkan temuan di lapangan bahwa evaluasi yang dilakukan oleh Kepala urusan hubungan masyarakat meninjau terhadap 3 (tiga) aspek sarana, meliputi (1) bidang sarana akademik, yaitu dengan meninjau terhadap keterampilan lulusan, hasil karya, kuantitastenaga pendidik, infrastruktur sarana dan prasarana perangkat pembelajaran; (2) bidang sarana pendidikan, yaitu meninjau terhadap kelayakan infrastruktur sarana dan prasarana penunjang popularitas sekolah; dan (3) bidang sosial, yaitu mengevaluasi peran warga sekolah dengan masyarakat agar menambah kesan dan kepedulian masyarakat terhadap perkembangan mutu sekolah.

Evaluasi sebagai peninjauan kembali kegiatan yang telah terlaksana dengan baik dan sesuai sasaran. Peninjauan berupa penilaian untuk mengkaji program-program yang telah disusun dan kemudian ditelaah. Sementara itu, Johnson (dalam Nasution, 2010) menyatakan bahwa evaluasi sebagai sistem untuk mendeteksi antara penyesuaian rencana dengan tujuan yang telah dibatasi. Dengan kata lain, pencapaian tujuan program Humas dievaluasi untuk mengukur terhadap rumusan tujuan yang telah ditetapkan dan untuk menilai programprogram tersebut berhasil dilaksanakan. Serangkaian kegiatan tersebut dilaksanakan untuk meningkatkan angka partisipasi sekolah terhadap mutu pendidikan melalui proses persiapan dan perencanaan yang matang (Rohiat, 2010). Berdasarkan uraian diatas, dapat disimpulkan bahwa pentingnya fungsi dan peran Humas di sekolah sebagai penyedia informasi baik intern maupun ekstern dalam rangka membangun partisipasi aktif orang tua dan masyarakat.

\section{Prosedur Operasional Hubungan Masyarakat di Sekolah}

Upaya mewujudkan kualitas mutu pendidikan melalui bidang kehumasan dirancang agar membentuk partispasi dari masyarakat untuk mendukung arah mutu pendidikan yang lebih baik, rancangan tersebut dibentuk dengan mengadakan kerjasama mutualisme dengan pihak lingkungan internal dan eksternal sekolah. Terdapat dua program kerja dalam prosedur hubungan masyarakat yaitu program umum dan program khusus. Bentuk kegiatan dari program umum meliputi kemitraan dengan instansi pemerintah dan wali murid. Sedangkan bentuk kegiatan dari program khusus meliputi pelaksanaan rapat koordinasi, kerjasama, melakukan kunjungan dan pemberian bantuan kepada warga sekolah. bentuk-bentuk program tersebut guna mempermudah warga sekolah dan masyarakat dalam mengakses informasi sekolah. Hal ini sejalan dengan pendapat Nasution (2010) peningkatan dalam hubungan masyarakat membutuhkan strategi sebagai cara alternatif untuk memaksimalkan tujuan yang direncanakan. Strategi yang telah dirumuskan dilaksanakan kemudian dievaluasi untuk menentukan strategi yang tepat selanjutnya. Manajemen humas yang diterapkan dengan baik 
dapat menciptakan mutu sekolah yang berkualitas, dengan pengadaan komunikasi serta jejaring yang baik dengan masyarakat (Rubinstein \& McCarthy, 2014, p. 9).

Beberapa temuan dalam prosedur operasional hubungan masyarakat di sekolah sebagai program kerja kehumasan antara lain, (1) mengatur koordinasi pertemuan kepala sekolah dengan komite dan masyarakat dalam mensosialisasikan citra sekolah serta pengadaan infrastruktur sarana dan prasarana pendidikan; (2) mengkoordinasikan pertemuan unsur sekolah dengan orang tua peserta didik untuk pengambilan buku hasil raport siswa; (3) mengatur strategi hubungan kerjasama unsur sekolah seperti; perkemahan, gotong royong, visit school, serta kegiatan perlombaan; dan (4) mengatur koordinasi hubungan kerjasama antar lembaga pendidikan terhadap feedback penyelenggaraan program kerja sekolah. Di sisi lain, dalam menjalankan prosedur operasional hubungan masyarakat terdapat beberapa prinsip yaitu keterpaduan, berkesinambungan, menyeluruh, sederhana, konstruktif, kesesuaian dan fleksibel. Ruang lingkup pengelolaan hubungan masyarakat terdapat pola manajemen yang dijalankan baik secara intern maupun ekstern (LeMahieu, Grunow, Baker, Nordstrum, \& Gomes, 2017), manajemen membutuhkan koordinasi yang baik dan harmonis antar sesama dalam upaya bersama mencapai tujuan dari lembaga pendidikan tersebut.

\section{Peran Kepala Sekolah dalam Meningkatkan Mutu Pendidikan}

Kedudukan kepala sekolah sebagai pemimpin lembaga pendidikan sangatlah menentukan terkait keberhasilan proses pendidikan peserta didik di sekolah (Adil, 2018), kepala sekolah mempunyai tanggungjawab dalam tercapainya tujuan pendidikan di sekolah. Kepala sekolah adalah inspirator serta motivator bagi unsur-unsur sekolah sehingga mendukung inovasiinovasi produktivitas dalam proses pembelajaran. Kepala sekolah diharapkan untuk mampu mempengaruhi dan memberikan motivasi kepada bawahannya dalam menjalankan tugas pokoknya masing-masing guna meningkatkan taraf mutu pendidikan.

Peran pemimpin di sekolah ini dikategorikan sangat baik dimana kepala sekolah sangat menguasai tentang teori-teori manajemen pendidikan meliputi dimensi perencanaan, aspek pengorganisasian, aspek pelaksanaan serta aspek pengawasan. Kepemimpinan kepala sekolah terhadap para guru tanpa ada sifat pemaksaan (otoriter) melainkan mengarahkan serta mengkomunikasikan dengan pemilihan kata yang tepat dalam mengevaluasi sehingga orang yang bersangkutan tidak tersinggung tapi memahami. Dalam memotivasi unsur-unsur sekolah, seorang kepala sekolah dituntut untuk memberikan motivasi dari luar tetap juga harus bisa menumbuhkan semangat dan motivasi dari dalam diri guru itu sendiri, sejalan dengan pemikiran Mujito \& Satiningsih (2006) menjelaskan bahwa motivasi untuk membangkitkan perilaku seorang guru digolongkan menjadi dua aspek, yaitu (1) motivasi intrinsik berupa dorongan dalam diri individu, dan (2) motivasi ekstrinsik berupa sumber dorongan dari luar.

Dapat disimpulkan bahwa pemberian motivasi bertujuan untuk mampu meningkatkan kinerja profesionalitas guru dalam pengajaran demi tercapai tujuan sekolah untuk dapat mencapai mutu pendidikan. Motivasi sangat dibutuhkan bagi seorang guru yang akan berdampak terhadap kinerjanya, kepala sekolah harus berperan aktif dengan berbagai penerapan program-program penunjang guna menjawab permasalahan guru dalam pembelajaran. Selanjutnya, kontrol dan evaluasi oleh kepala sekolah dalam pengelolaan sekolah meliputi dimensi perencanaan, pengorganisasian, pelaksanaan serta pengawasan. Evaluasi yang dilakukan oleh kepala sekolah dalam perencanaan, pengorganisasian, hingga pelaksanaan program peningkatan mutu sekolah penting dilakukan (Strunk, Marsh, Bush, \& Duque, 2016).

Kepala sekolah memonitoring kinerja para guru guna memperoleh data yang objektif berdasarkan pengamatan terhadap pengembangan setiap guru disekolah. Kegiatan monitoring 
oleh kepala sekolah dilakukan setiap pagi hari seperti meninjau lingkungan sekolah dengan cara mengambil gambar atau foto dari keadaan lingkungan yang tidak berkenan atau tidak sesuai yang kemudian staf yang bersangkutan dipanggil dan menunjukkan bukti tanpa banyak bicara. Dalam monitoring individu dilakukan secara berkala dengan datang langsung pada kelas yang sedang melaksanakan proses pembelajaran dan juga dengan cara meminta bantuan staf dalam memonitoring guru. Guru-guru senior di monitoring serta mengawasi secara langsung oleh kepala sekolah dan guru-guru baru dibantu guru senior dalam kegiatan monitoring dan evaluasi.

Begitu halnya juga dalam melakukan evaluasi, seluruh rangkaian dalam melaksanakan kegiatan pembelajaran siswa menjadi tolak ukur penilaian kinerja guru. Tujuan dari pelaksanaan monitoring dan evaluasi dilakukan guna kepentingan dalam pengambilan keputusan terhadap seluruh kegiatan pembelajaran, sehingga pengambilan keputusan menjadi lebih baik dalam menjalankan dan menyempurnakan.

\section{SIMPULAN}

Proses peningkatan mutu pendidikan tersebut tentunya melalui langkah strategis manajemen sekolah dalam upaya menigkatkan mutu sekolah. Dalam mengelola hubungan masyarakat dengan sekolah tentunya dibutuhkan proses perencanaan, pelaksanaan dan evaluasi pihak sekolah dalam merancang program-program yang mendukung kegiatan sekolah baik secara internal maupun eksternal. Pertama: perencanaan yang dilakukan oleh Kepala Urusan Humas melibatkan seluruh elemen lingkungan sekolah, mengagendakan rapat pelaksanaan kegiatan sekolah dan mengaplikasikan kerjasama antara sekolah dengan stakeholder pendidikan, orang tua maupun masyarakat meliputi kegiatan eksternal dan internal sekolah. Pelaksanaan kegiatan dalam program Humas meliputi beberapa kegiatan antara lainKegiatan eksternal dan kegiatan internal sekolah, dan evaluasi pada aspek akademik, infrastruktur pembelajaran dan aspek sosial. Kedua: Prosedur operasional hubungan masyarakat di sekolah sebagai program kerja kehumasan dengan mensosialisasikan citra sekolah serta pengadaan infrastruktur sarana dan prasarana pendidikan, pertemuan dengan peserta didik, mengatur strategi hubungan kerjasama unsur sekolah dan hubungan kerjasama antar lembaga pendidikan. Ketiga: peran kepemimpinan dikategorikan sangat baik dimana kepala sekolah sangat menguasai tentang teori-teori manajemen pendidikan meliputi dimensi perencanaan, pengorganisasian, pelaksanaan serta pengawasan.

\section{DAFTAR PUSTAKA}

Adha, M. A., Benyamin, C., Octaviarnis, I., \& Thalib, D. (2019). Peran Akreditasi Dalam Penjaminan Mutu Pendidikan Di Sekolah Dasar. Media Manajemen Pendidikan, 2(2), 270-278. https://doi.org/10.30738/mmp.v2i2.5780

Adil, C. (2018). School Principal's Opinions about Public Relations Practices on Schools. International Journal of Progressive Education, 14(2), 136-147.

Ariyanti, N. S., Sobri, A. Y., \& Kusumaningrum, D. E. (2018). Kepemimpinan Kepala Sekolah dalam Meningkatkan Partisipasi Masyarakat. Jurnal Administrasi Dan Manajemen Pendidikan, 1(4), 1-6. Retrieved from http://journal2.um.ac.id/index.php/jamp/article/view/2489/1714

Asmi, E., \& Sahuri, C. (2013). Pelayanan Sekolah Untuk Meningkatkan Kualitas Pendidikan. Jurnal Kebijakan Publik, 4 (1), 51-56.

Ayu, I., \& Septi, Y. (2012). Strategi Peningkatan Mutu Manajemen Melalui Pengembangan Program Sekolah. Jurnal Manajemen Pendidikan, 23 (5), 445-453.

Creswell, J. W. (2014). Research Design: Qualitative, Quantitative, and Mixed Methods Approaches 4th Edition. London: Sage Publication. 
Dhuhani, E. M. (2016). Manajemen Humas Dalam Meningkatkan Mutu Madrasah Studi Kasus Di Madrasah Ibtidiyah Terpadu (MIT) As-Salam Ambon. Jurnal Al-Iltizam, 1 (1), 11-20.

Grace, R.A., \& Harrington, S.Y. (2015). Our Children, Our School: Seeking Solutions for Improving the Climate in Urban Public Schools. Alabama Journal of Educational Leadership, 2 (1), 1-14.

Kowalski, T.J. (2011). Public Relations in Schools (5th Edition). London: Pearson.

Lemahieu, P.G., Grunow, A., Baker, L., Nordstrum, L.E., \& Gomes, L.M. (2017). Networked Improvement Communities: The Disciplines of Improvement Science Meets The Power of Network. Quality Assurance in Education, 25 (1), 5-25.

Mujito., \& Satiningsih. (2006). Strategi Peningkatan Motivasi Kinerja Guru. Yogyakarta: Multi Presindo.

Murniati. (2008). Manajemen Stratejik: Peran Kepala Sekolah dalam Pemberdayaan. Bandung: Citapustaka Media Perintis.

Nasution, Z. (2010). Manajemen Humas Di Lembaga Pendidikan. Malang: UMM Press.

Rohiat. (2010). Manajemen Sekolah Teori Dasar dan Praktik. Bandung: Refika Aditama.

Rubinstein, S.A., \& McCarthy. (2014). Teachers Union and Management Partnership: How Working Together Improving Student Achievement. Washington DC: Center for American Progress.

Ruslan, R. (2007). Manajemen Public Relations dan Media Komunikasi Konsepsi dan Aplikasi. Jakarta: Raja Grafindo Persada.

Strunk, K.O., Marsh, J.A., Bush-Mecenas, S.C., \& Duque, M.R. (2016). The Best Laid Plans: An Examination of School Plan Quality and Implementation in a School Improvement Initiative. Educational Administration Quarterly, 52 (2), 259-309.

Suryosubroto, B. (2012). Hubungan Sekolah Dengan Masyarakat (School Public Relation). Jakarta: PT. Rineka Cipta.

Sutrisno., \& Rusdi, M. (2007). Analisis Kebijakan Peningkatan Mutu Pendidikan Dasar dan Menengah di Provinsi Jambi. Jurnal Pendidikan Inovatif, 3 (1), 25-31.

Tianping, Y. (2003). On The Development of Schools External Public Relation in China. International Journal of Leadership in Education, 6 (2), 185-191.

Ulfatin, N. (2015). Metode Penelitian Kualitatif di Bidang Pendidikan: Teori dan Aplikasinya. Malang: Media Nusa Creative.

Wahjosumidjo. (2010). Kepemimpinan Kepala Sekolah. Jakarta: PT Raja Grafindo. 